\title{
POTENTIAL OF PUMPKIN OIL CAKE PROTEIN ISOLATE IN PRODUCTION OF MILLET BREAD
}

\author{
Jelena M. Tomić* ${ }^{*}$, Aleksandra M. Torbica ${ }^{1}$, Miona M. Belović ${ }^{1}$, Ljiljana M. Popović ${ }^{2}$, Jelena C. \\ Čakarević $^{2}$, Danica M. Savanović ${ }^{3}$, Aleksandra R. Novaković ${ }^{1}$, Karolina A. Mocko Blažek ${ }^{1}$ \\ ${ }^{1}$ University of Novi Sad, Institute of Food Technology, 21000 Novi Sad, Bulevar cara Lazara 1, Serbia \\ ${ }^{2}$ University of Novi Sad, Faculty of Technology, Bulevar cara Lazara 1, 21000 Novi Sad, Serbia \\ ${ }^{3}$ University of Banja Luka, Faculty of Technology, 78000 Banja Luka, Bulevar vojvode Stepe \\ Stepanovića 73, Bosnia and Herzegovina
}

\author{
${ }^{*}$ Corresponding author: \\ Phone: +381214853780 \\ Fax: +38121450725 \\ E-mail address: jelena.tomic@fins.uns.ac.rs
}

\begin{abstract}
The objective of this study was to evaluate the potential of pumpkin oil cake protein isolate in production of millet bread. For that purpose, breads were created by substitution of millet flour with proteins at 5, 10 and 15\% level. Dough rheological properties and both physical and sensory characteristics of obtained bread were determined. The increase in pumpkin oilseed cake protein (POCP) concentration influenced increase in dough viscosity, as determined using farinograph and fundamental rheological measurements. This is additionally confirmed by lower elasticity of supplemented breads as determined by texture analysis and sensory panel. Substitution of millet flour with POCP at all tested levels did not exhibit any influence on bread specific volume. However, $24 \mathrm{~h}$ after baking, breads supplemented with higher amount of POCP showed less pronounced hardening of the crumb, indicating that these proteins might retard starch retrogradation. The supplementation of millet bread with POCP had several beneficial effects on the sensory quality of bread, such as loss of bitter taste and aftertaste originating from millet flour. Additionally, bread granularity decreased and bread dissolving speed in mouth increased along with the increase in POCP concentration.
\end{abstract}

Key words: pumpkin oil cake, millet bread, dough rheological properties, sensory quality

\section{INTRODUCTION}

The development of gluten free products is a very complex task since the prohibited ingredients are at the same time components that provide functional properties for bakery products (Gallagher et al., 2004). There are different approaches in formulation of GF food products with enhanced functional properties which include various pre-treatment techniques of raw materials as well as addition of various ingredients which could improve rheological behaviour, texture and sensory characteristics of the final product. Among the ingredients that have been used to imitate the viscoelastic properties of gluten, proteins especially whey, soybean and pea proteins gained great attention. The role of proteins in gluten free formulations is twofold. Besides its role as a techno-functional ingredient, incorporation of proteins is valuable at a nutritional level bearing in mind low nutritional quality of this type of products. Proteins of both animal (whey powder, sodium and calcium caseinate, egg albumin, collagen) and plant origin (soybean, pea, lupine, potato) (Gallagher 
et al., 2003; Ziobro et al., 2013; Ronda et al., 2014; Witczak et al., 2017) were used as functional components of gluten free products. However, proteins are often used in combination with other structuring agents (xanthan gum, guar gum, locust bean gum, hydroxypropylmethylcellulose) and processing aids (emulsifiers and transglutaminase) (Marco and Rosell, 2008; Demirkesen et al., 2010).

By exploring future trends, it could be presumed that demands for nutritional fortification of gluten free products will shift towards alternative protein sources depending on its availability, quality and prices. Food waste is a cheap source of valuable components, and its valorisation represents a basis of sustainable development and circular economy. Valuable components which could be recovered from food waste also include proteins, with trend towards diets containing less animal protein and more plant protein (Aiking, 2011). Nevertheless, the majority of research papers have been focused on utilization of animal originated wastes (Mirabella et al., 2014) neglecting the fact that oilseed cakes, residues from oil refining industry, also contain high amount of proteins that are too valuable to be discarded in the environment (Rodrigues et al., 2012). Additionally, proteins obtained from plant sources are also important for consumers of both gluten free and vegetarian/vegan diet.

Pumpkin (Cucurbita spp.) oil is widely produced in Central Europe and Balkan countries. After oil extraction from pumpkin seeds, oil cake remains as a by-product which is rich in proteins (63\%) (Popović et al., 2011). The most prominent protein fractions are albumins and globulins making up about $59 \%$ of the total crude protein content (Fruhwirth and Hermetter, 2007). The isolation of proteins and their modification either by hydrolysis (Vaštag et al., 2011) or cross-linking using transglutaminase (Popović et al., 2013) are the proposed methods for the valorisation of pumpkin oilseed cake. The obtained hydrolysates were shown to have potential health benefits, such as antioxidant activity and angiotensin-converting I enzyme (ACE) inhibition (Vaštag et al., 2011).
Cross-linking of pumpkin oilseed cake protein by transglutaminase modifies its solubility and improves its gelation properties, indicating its potential application in food products. (Popović et al., 2013).

There are several papers about oilseed cake implementation in bread making, including flax oilseed cake (Ogunronbi et al., 2011) and hemp oilseed cake (Pojić et al., 2015). Pumpkin oilseed cake was used for bread fortification in the study of TarekTilistyák et al. (2014). However, to the best of our knowledge, there are no studies where pumpkin oilseed cake protein was used for bread supplementation. The current market situation regarding gluten free bakery products assortment, as well as necessity for more efficient ways of food by-product valorisation, have determined the objective of this study, in which bread made from proso millet (Panicum miliaceum) flour and pumpkin oilseed cake protein was developed and evaluated.

\section{MATERIALS AND METHODS}

Proso millet flour was purchased from a local market, while pumpkin (Cucurbita pepo) oil cake protein isolate (POCP) with protein content of $94.3 \mathrm{~g} / 100 \mathrm{~g}$ was obtained by alkali extraction with isoelectric precipitation (Vaštag et al., 2011).

\section{Bread making procedure}

Basic dough recipe on $100 \mathrm{~g}$ proso millet flour basis consisted of $5 \%$ sugar, $4 \%$ yeast and $2.5 \%$ salt. The amount of water $\left(30{ }^{\circ} \mathrm{C}\right)$ added to the millet flour dough was $110 \%$. After mixing, the dough was divided into $150 \mathrm{~g}$ portions and placed in baking pans $\left(9.5 \times 7.5 \mathrm{~cm}^{2}\right.$ upper extent, $7.5 \times 5.5$ $\mathrm{cm}^{2}$ lower extent and $6.5 \mathrm{~cm}$ deep). After proofing of $30 \mathrm{~min}$ at $30{ }^{\circ} \mathrm{C}$, the loaves were baked at $220{ }^{\circ} \mathrm{C}$ for $20 \mathrm{~min}$. After cooling for $1 \mathrm{~h}$, loaves were packed in polypropylene bags and stored at $24{ }^{\circ} \mathrm{C}$ for $24 \mathrm{~h}$. The bread quality assessment was done after $1 \mathrm{~h}$ of cooling and after 24 $\mathrm{h}$ of storage.

\section{Rheological measurements}

The effect of pumpkin oilseed cake protein substitution at three levels (5, 10 and 15\%) on dough mixing properties of millet flour was investigated by Brabender farinograph (OHgG, Duisburg, Germany) using 
$10 \mathrm{~g}$ mixer according to Hungarian standard method MSZ 6369/6 (Hungarian Standard, 1988).

Dynamic oscillatory measurements of doughs were performed using HAAKE MARS Rheometer (Thermo Scientific, Karlsruhe, Germany). Dough samples for the rheological tests were prepared as those used in bread making but without added yeast. The rheometer was equipped with parallel plate geometry measuring system (60 mm diameter, $1 \mathrm{~mm}$ gap). Frequency sweeps were measured in the range $0.1-10 \mathrm{~Hz}$ at $1 \mathrm{~Pa}$ stress (which was within the linear viscoelastic region as determined by amplitude sweep). Temperature during the test was kept constant at $25^{\circ} \mathrm{C}$ using Peltier system. Two replicates at least were performed for each analysis.

\section{Chemical composition and protein di- gestibility}

Moisture content, protein, fat, and total sugars content of obtained breads were determined according to Association Official of Analytical Chemists (AOAC, 2000) methods 925.10, 950.36, 935.38, and according to standard AACC methods 80-68. Total starch content was determined according to ISO standards 10520:1997. Protein digestibility was determined as described by Duodu et al. (2002). Two replicates were performed for each analysis.

\section{Volume, colour and texture measure- ments}

The volume of bread loaves was determined using laser measuring device VolScan Profiler 600 (Stable Micro Systems, England). Laser step was set to $1 \mathrm{~mm}$ and rotation speed was set to $1 \mathrm{rps}$. Specific volume was calculated as the volume to mass ratio $(\mathrm{ml} / \mathrm{g})$. Measurement of bread colour was performed by a Chroma Meter CR-400 (Konica Minolta Co., Ltd., Osaka, Japan. The colour of crust and crumb were measured at five points. CIE $L^{*}$ (lightness), CIE $a^{*}\left(+a^{*}=\right.$ redness, $-a^{*}=$ greenness $)$ and $\mathrm{CIE} b^{*}\left(+b^{*}\right.$ $=$ yellowness, $-b^{*}=$ blueness ) were read using a D65 light source and the observer angle of $2^{\circ}$. Texture profile analysis (TPA) was performed using TA.XT Plus Texture Analyser (Stable Micro Systems, Godalming, UK). Instrumental settings for TPA test (TPA.PRJ) were taken from the software package (Texture Exponent Software TEE32, version 6,0,6,0, Stable Micro Systems, Godalming, UK). Breads were cut using a meat slicer (Krups, Solingen, Germany) into slices with approximate height of $12.5 \mathrm{~mm}$. Cylinders wit-h a diameter of $35 \mathrm{~mm}$ were taken from the bread crumb using the bakery mould. The bread crumb cylinders were compressed twice with a $100 \mathrm{~mm}$ diameter stainless steel cylinder $(P / 100)$ to the strain of $50 \%$, while a $30 \mathrm{~kg}$ load cell was equipped. Measurements were taken in triplicates.

\section{Sensory analysis}

Sensory analysis of breads was done by eight expert panellists from the Institute of Food Technology (University of Novi Sad, Serbia) with sensory experience in evaluation of different types of bakery products. The list of descriptors was established in several sessions as described in ISO 11035 (ISO, 1994), taking into consideration previously published list (Callejo, 2011). Afterwards, samples were evaluated by the panel using an unstrucktured $100 \mathrm{~mm}$ linear scale with the anchor points 0 - not perceptible and 100 strongly perceptible (ISO, 2003). During the training sessions, all descriptors which were not perceptible in all samples were eliminated from the final evaluation. Testing using the final descriptors was performed in tasting booths with controlled environment conditions (ISO, 2015) in two sessions. Bread samples were presented in randomized order on the plastic plates. Drinking water was provided for palate cleansing after testing of each sample.

\section{Data analysis}

One-way analysis of variance (ANOVA) and Tukey's honest significant differences (HSD) test were applied at a significance level of $5 \%$ to determine differences among analysed samples using Statistica 13.3 software (TIBCO Software Inc., USA, 2016).

\section{RESULTS AND DISCUSSION}

The effect of protein isolate substitution on the farinographic characteristics of the millet flour dough can be seen in Figure 1. 
How millet flour does not possess the ability to form viscoelastic dough, the addition of water at different levels did not provide the consistency of 500 BU (results not shown). Moreover, the signal of the curve was very noisy. After preliminary results, it was concluded that the most appropriate water content for recording the curves was $40 \%$. In order to estimate the influence of protein substitution on millet flour dough characteristics, this amount of water was held constant. The standard farinograph curve obtained for the pure millet flour used in this study showed the consistency of $251 \mathrm{BU}$ with noisy signal showing poor dough baking quality. The presence of pumpkin oil cake proteins caused pronounced noisy signal of curve and continuous increase in dough consistency with measurement time. The highest consistency was obtained for the highest level of proteins. These results indicated that proteins have beneficial effect on millet flour dough in terms of consistency but there are still shortcomings such as long dough development time and lower water absorption which could be probably overcame by the addition of hydrocolloids. They are commonly used in gluten free bread formulation in order to improve viscoelastic properties, through stabilization of ingredients by preventing phase separation, foam collapse and crystallization (Mir et al., 2016).

For all doughs, elastic modulus $\left(G^{\prime}\right)$ was higher than the viscous modulus ( $\left.G^{\prime \prime}\right)$, indicating that the doughs had a solid, elastic-like behaviour (Figure 2). According to the obtained mechanical spectra, dough samples could be separated into two groups. The first group consisted of control sample and sample with 5\% POCP, while the second group consisted of samples with 10 and $15 \%$ POCP.

Therefore, it can be concluded that the substitution of millet flour with POCP in smaller amount did not influence rheological properties of dough. However, higher levels of POCP caused a slight increase in storage modulus and more pronounced increase in loss modulus. The increase in both moduli as a consequence of protein addition to gluten free dough was observed by several authors (Ziobro et al., 2013; Ronda et al., 2014; Witczak et al., 2017).

Higher increase in loss moduli can be explained by the structure of pumpkin oilseed cake protein, which contains over $50 \%$ of albumins and globulins (Fruhwirth and Hermetter, 2007). Since albumins and globulins cannot build strong networks as gluten proteins (Shewry and Halford, 2002), it can be supposed that their main contribution is through the increase of viscosity. The increase in dough viscosity led to the stabilization of foam resulting from dough mixing, causing that breads with 10 and 15\% POCP had smaller but evenly distributed pores (Figure 3 ).

The chemical composition of obtained bread is shown in Table 1. As expected, protein content increased while total starch content decreased with increase of substitution level. On the other hand, there was no clear trend of moisture decrease with increase of substitution level. Regarding the protein digestibility, substitution of millet flour with POCP resulted in an increase in protein digestibility of the obtained breads by approximately 20 to $30 \%$.

Millet and millet based products are known to have lower protein digestibility when compared to other cereals. The lower protein digestibility could be caused by various factors, such as the presence of tannins, i.e. polyphenols that bind to proteins or could be affected by various foodprocessing methods (Annor et al., 2017).

Taking into account all mentioned above, the implementation of this type of protein in the millet based products is appropriate step to improve its nutritional quality.

The effect of pumpkin oil cake protein on colour properties and bread specific volume is illustrated in Table 2. Sub-stitution of millet flour with POCP at all tested levels did not exhibit any influence on bread specific volume. Also, it is possible to observe that all breads had com-pact crumb structure with few pores (Figure 3).

The most compact structure with small number of large pores is obtained for control bread. 

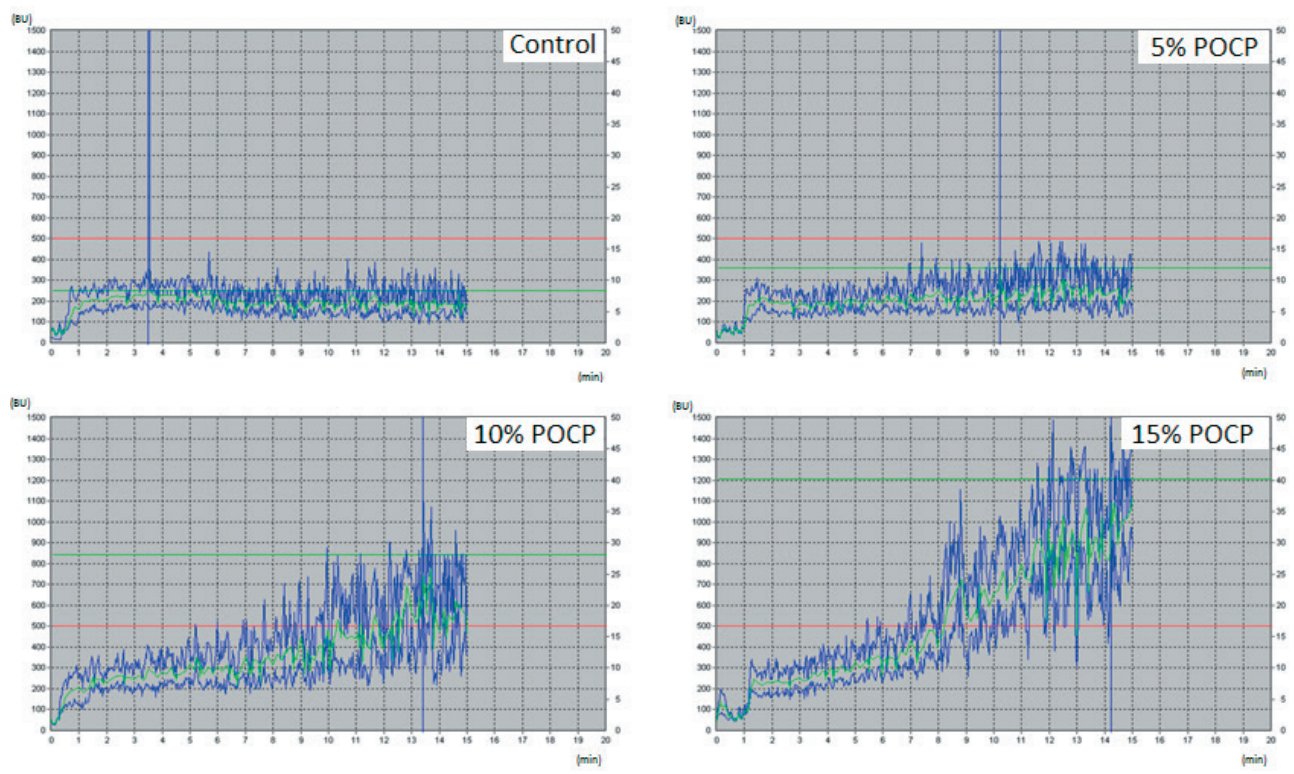

Figure 1. Effect of pumpkin oil cake protein (POCP) substitution on rheological properties determined by farinograph of millet dough; pumpkin oil cake protein (POCP) were substituted at 5, 10 and $15 \%$ level (millet flour basis)
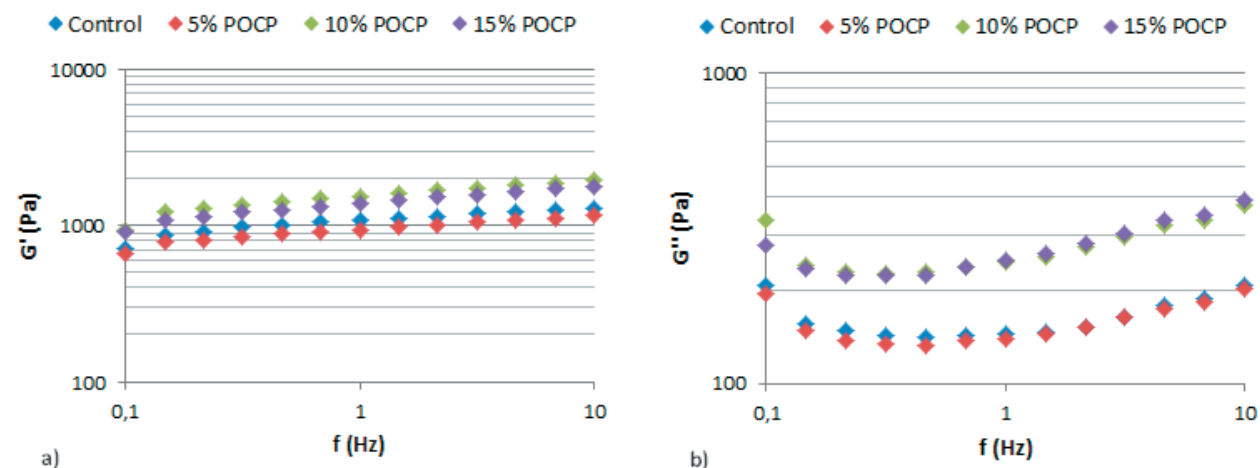

Figure 2. Storage (a) and loss (b) moduli of millet dough prepared with different concentrations $(0,5,10$ and $15 \%)$ of pumpkin oil cake protein (POCP)

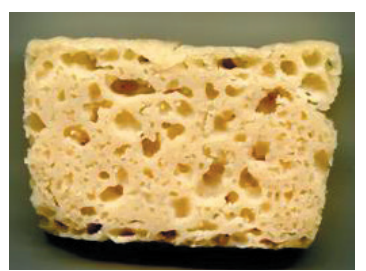

Control

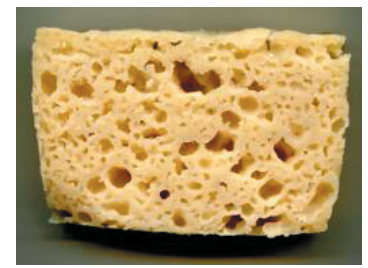

$5 \%$ POCP

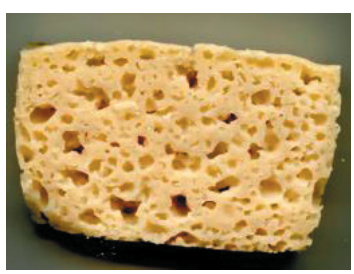

$10 \%$ POCP

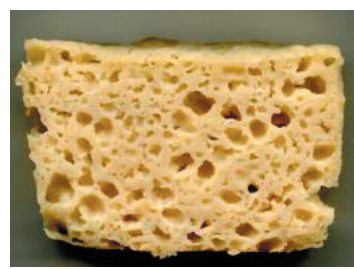

$15 \%$ POCP

Figure 3. Cross-sectional photographs of representative loaves
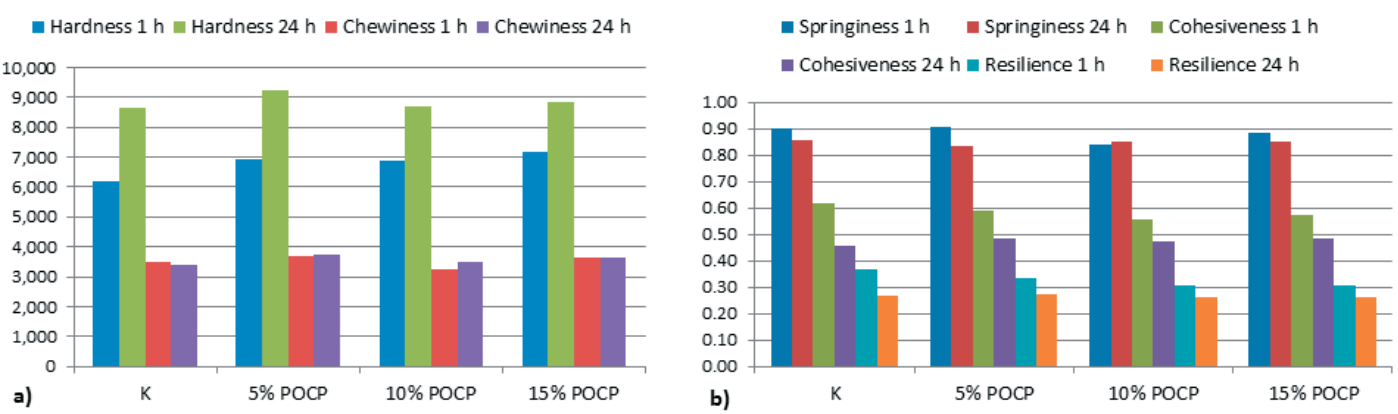

Figure 4. Textural properties of breads prepared by substitution of millet flour with different concentrations $(0,5$, 10 and $15 \%$ ) of pumpkin oil cake protein (POCP); a) hardness and chewiness; b) springiness, cohesiveness and resilience 
Table 1.

Chemical composition and protein digestibility of bread samples

\begin{tabular}{lcccc}
\hline & Control & 5\% POCP & $10 \%$ POCP & 15\% POCP \\
\hline Moisture (\%) & $50.40 \pm 0.03^{\mathrm{b}}$ & $48.59 \pm 0.02^{\mathrm{c}}$ & $50.62 \pm 0.05^{\mathrm{a}}$ & $44.87 \pm 0.04^{\mathrm{d}}$ \\
Protein (\%) & $3.55 \pm 0.13^{\mathrm{d}}$ & $5.09 \pm 0.08^{\mathrm{c}}$ & $5.76 \pm 0.00^{\mathrm{b}}$ & $8.43 \pm 0.21^{\mathrm{a}}$ \\
Fat (\%) & $1.61 \pm 0.04^{\mathrm{b}}$ & $1.86 \pm 0.02^{\mathrm{a}}$ & $1.61 \pm 0.03^{\mathrm{b}}$ & $1.13 \pm 0.04^{\mathrm{c}}$ \\
Sugars (\%) & $2.37 \pm 0.00^{\mathrm{b}}$ & $2.78 \pm 0.10^{\mathrm{a}}$ & $2.29 \pm 0.10^{\mathrm{b}}$ & $2.55 \pm 0.00^{\mathrm{ab}}$ \\
Total starch (\%) & $34.57 \pm 0.00^{\mathrm{a}}$ & $32.46 \pm 0.14^{\mathrm{c}}$ & $32.23 \pm 0.00^{\mathrm{c}}$ & $33.26 \pm 0.14^{\mathrm{b}}$ \\
Protein digestibility (\%) & $49.93 \pm 1.66^{\mathrm{c}}$ & $73.75 \pm 0.00^{\mathrm{b}}$ & $76.81 \pm 0.00^{\mathrm{b}}$ & $84.65 \pm 0.70^{\mathrm{a}}$ \\
\hline
\end{tabular}

Results are expressed as means \pm standard deviations $(n=2)$. Values in rows with different letters are significantly different $(P<0.05)$

Table 2.

Bread specific volume and colour properties of bread samples

\begin{tabular}{|c|c|c|c|c|c|}
\hline \multirow{2}{*}{\multicolumn{2}{|c|}{$\begin{array}{l}\text { Sample } \\
\text { Crust }\end{array}$}} & Control & $5 \%$ POCP & $10 \%$ POCP & $15 \%$ POCP \\
\hline & & $60.72 \pm 1.77^{\mathrm{a}}$ & $60.92 \pm 2.11^{a}$ & $62.77 \pm 3.40^{\mathrm{a}}$ & $56.22 \pm 0.88^{b}$ \\
\hline$L^{*}$ & Crumb & $69.64 \pm 1.46^{a}$ & $67.71 \pm 2.83^{\mathrm{a}}$ & $69.41 \pm 1.08^{\mathrm{a}}$ & $69.95 \pm 1.77^{\mathrm{a}}$ \\
\hline \multirow{3}{*}{$a^{*}$} & Crust & $-0.50 \pm 0.22^{b}$ & $-0.39 \pm 0.17^{b}$ & $-0.20 \pm 0.28^{\mathrm{b}}$ & $0.44 \pm 0.22^{\mathrm{a}}$ \\
\hline & Crumb & $-1.40 \pm 0.23^{\mathrm{ab}}$ & $-1.24 \pm 0.23^{\mathrm{a}}$ & $-1.49 \pm 0.11^{a b}$ & $-1.62 \pm 0.21^{b}$ \\
\hline & Crust & $26.91 \pm 1.16^{a}$ & $27.89 \pm 1.44^{\mathrm{a}}$ & $28.75 \pm 1.07^{\mathrm{a}}$ & $27.55 \pm 0.67^{\mathrm{a}}$ \\
\hline $\mathbf{b}^{*}$ & Crumb & $22.20 \pm 0.65^{b}$ & $22.78 \pm 0.67^{\mathrm{ab}}$ & $23.14 \pm 0.53^{\mathrm{ab}}$ & $23.39 \pm 0.49^{a}$ \\
\hline \multicolumn{2}{|c|}{$\begin{array}{l}\text { Spec. volume } \\
(\mathrm{m} / / \mathrm{a})\end{array}$} & $1.25 \pm 0.02^{\mathrm{a}}$ & $1.20 \pm 0.03^{\mathrm{a}}$ & $1.19 \pm 0.01^{\mathrm{a}}$ & $1.24 \pm 0.03^{\mathrm{a}}$ \\
\hline
\end{tabular}

Results are expressed as means \pm standard deviations for all replicates. Values in rows with different letters are significantly different $(P<0.05)$

Table 3.

Sensory properties of breads prepared by substitution of millet flour with different concentrations $(0,5$, 10 and $15 \%$ ) of pumpkin oil cake protein (POCP)

\begin{tabular}{|c|c|c|c|c|c|c|c|c|}
\hline \multirow[b]{2}{*}{ Sample } & \multicolumn{4}{|c|}{ After $1 \mathrm{~h}$} & \multicolumn{4}{|c|}{ After $24 \mathrm{~h}$} \\
\hline & Control & $\begin{array}{c}5 \% \\
\text { POCP }\end{array}$ & $\begin{array}{c}10 \% \\
\text { POCP }\end{array}$ & $\begin{array}{c}15 \% \\
\text { POCP }\end{array}$ & Control & $\begin{array}{c}5 \% \\
\text { POCP }\end{array}$ & $\begin{array}{c}10 \% \\
\text { POCP }\end{array}$ & $\begin{array}{c}15 \% \\
\text { POCP }\end{array}$ \\
\hline \multicolumn{9}{|l|}{ Appearance } \\
\hline $\begin{array}{r}\text { Shape } \\
\text { regularity }\end{array}$ & 48.0 & 69.0 & 82.0 & 55.0 & 48.0 & 69.0 & 82.0 & 55.0 \\
\hline $\begin{array}{l}\text { Intensity of } \\
\text { crust colour }\end{array}$ & 5.0 & 11.0 & 17.0 & 26.5 & 5.0 & 11.0 & 17.0 & 26.5 \\
\hline $\begin{array}{r}\text { Surface } \\
\text { roughness }\end{array}$ & 75.0 & 63.5 & 44.5 & 42.5 & 75.0 & 63.5 & 44.5 & 42.5 \\
\hline Pore size & 30.5 & 50.0 & 60.0 & 67.5 & 30.5 & 50.0 & 60.0 & 67.5 \\
\hline \multicolumn{9}{|l|}{ Odour } \\
\hline Yeast odour & 59.0 & 37.0 & 23.5 & 15.0 & 38.0 & 24.5 & 11.0 & 1.5 \\
\hline \multicolumn{9}{|l|}{ Flavour } \\
\hline Yeast flavour & 26.5 & 5.5 & 0.0 & 0.0 & 24.5 & 0.0 & 0.0 & 0.0 \\
\hline \multicolumn{9}{|c|}{ Texture (mouthfeel) } \\
\hline $\begin{array}{r}\text { Crumb } \\
\text { elasticity }\end{array}$ & 46.0 & 37.5 & 21.0 & 22.5 & 36.0 & 26.0 & 14.0 & 14.0 \\
\hline $\begin{array}{r}\text { Cohesiveness } \\
\text { Graininess }\end{array}$ & $\begin{array}{l}65.5 \\
54.0\end{array}$ & $\begin{array}{l}43.5 \\
35.5\end{array}$ & $\begin{array}{l}29.5 \\
18.0\end{array}$ & $\begin{array}{c}23 \\
18.0\end{array}$ & $\begin{array}{l}73.5 \\
73.5\end{array}$ & $\begin{array}{l}64.5 \\
62.5\end{array}$ & $\begin{array}{l}43.0 \\
38.5\end{array}$ & $\begin{array}{l}28.0 \\
26.0\end{array}$ \\
\hline $\begin{array}{l}\text { Moistness of } \\
\text { bread crumb }\end{array}$ & 56.0 & 56.0 & 56.0 & 56.0 & 20.5 & 32.0 & 53.0 & 65.0 \\
\hline \multicolumn{9}{|l|}{ Taste } \\
\hline Bitter taste & 23.0 & 0.0 & 0.0 & 0.0 & 20.5 & 0.0 & 0.0 & 0.0 \\
\hline Salt taste & 60.0 & 50.0 & 36.0 & 21.5 & 48.0 & 30.5 & 18.0 & 9.5 \\
\hline Sweet taste & 9.3 & 16.5 & 23.3 & 30.3 & 6.3 & 11.0 & 17.0 & 22.8 \\
\hline Aftertaste & 13.5 & 0.0 & 0.0 & 0.0 & 17.5 & 0.0 & 0.0 & 0.0 \\
\hline
\end{tabular}


Regarding the colour measurement, the substitution with proteins caused increase in red tone $\left(a^{*}\right)$ of the bread crust due to higher content of amino acids which enhanced the Maillard reactions during baking. This conclusion is consistent with the results of studies by Giuberti et al. (2018) who reported the increase of red tone $\left(a^{*}\right)$ and decrease of the lightness $\left(L^{*}\right)$ due to the higher total protein content in gluten free rice cookies.

Texture changes of starch based breads are caused primarily by water migration from crumb to crust and recrystallization of starch polymers. Since in these breads water is bound only by polysaccharides, they stale much faster than wheat bread which contains gluten (Ziobro et al., 2013). As expected, staling caused increase in bread hardness (Figure 4a), with no significant difference observed between the bread samples analysed at the same time. However, the increase in POCP substitution caused less pronounced hardness increase after $24 \mathrm{~h}$ (33.2, 25.9 and 23.3\% for 5,10 and $15 \%$ of substitution, respectively) when compared to control sample $(39.1 \%$ of hardness increase), which is in accordance with results of Ziobro et al. (2013). These results suggest that the millet flour substitution by POCP can slow down starch retrogradation in bread loaves. On the other hand, both substitution with protein and staling process did not influence the chewiness of bread samples. This could be explained by the fact that chewiness is parameter derived from hardness, cohesiveness and springiness. In the tested samples hardness increased simultaneously with the decrease in cohesiveness, while springiness was relatively constant, making the final result similar in all breads.

Bread springiness varied in narrow range, without any trend (Figure 4b). Regarding cohesiveness, the greatest significant differrence was observed between control sample analysed after 1 and $24 \mathrm{~h}$, while the values for other samples varied inside that range. Generally, cohesiveness was lower for bread samples analysed after 24 $h$, which can be directly linked to increased bread crumbliness caused by starch retrogradation. Fresh samples were signifi- cantly different in terms of resilience, while after $24 \mathrm{~h}$ there were no significant differences between the samples. In fresh samples, resilience decreased with increase in protein concentration from 0 to $10 \%$, without significant difference observed between 10 and 15\% POCP substitution. This also contributes to the conclusion that the nature of these proteins is not elastic and that they only increase the viscosity of bread dough.

The substitution with protein caused loss of bread sample aftertaste (Table 3), which is related to the loss of bitter taste originating from millet flour. POCP also caused lowering of yeast odour intensity and complete loss of yeast flavour during consumption. The increase in POCP concentration caused increase in sweet taste, which was expected since the protein isolate has sweet taste, as determined during the preliminary sensory evaluation. Sweet taste originating from protein masked salty taste originating from table salt, causing decrease of salty taste with increase in POCP concentration despite the fact that all bread samples were prepared with the same amount of table salt. POCP addition led to reduction of bread graininess and decrease of cohesiveness. However, elasticity decreased with the increase in protein concentration which is in accordance with results obtained for bread resilience. After 24 hours, yeast odour, sweet and salty taste, elasticity and dissolving in mouth were less pronounced, while the granularity increased. It could be concluded that substitution by POCP not only influenced positively bread odour, taste, flavour and textural properties, but also slightly retarded bread staling.

\section{CONCLUSIONS}

The increase in pumpkin oilseed cake protein (POCP) concentration influenced increase in dough viscosity, as determined using farinograph and fundamental rheological properties. This increase in dough viscosity was not accompanied by the formation of strong protein network within the dough, which is supposed to be the consequence of predominantly globular shape of POCP. This is additionally confirmed by lower elasticity of supplemented 
breads as determined by texture analysis and sensory panel. The substitution by POCP did not cause any improvement of bread volume. However, $24 \mathrm{~h}$ after baking, breads supplemented with higher amount of POCP showed less pronounced hardening of crumb, indicating that these proteins might retard starch retrogradation. The supplementation of millet bread with POCP had several beneficial effects on the sensory quality of bread, such as loss of bitter taste and aftertaste originating from millet flour. Additionally, bread graininess and bread cohesiveness decreased along with the increase in POCP concentration.

\section{ACKNOWLEDGEMENTS}

This paper is a result of the research within the project TR31007 financed by the Ministry of Education, Science and Technological Development, Republic of Serbia and the project 142-451-2820/2018 financed by the Provincial Secretariat for Science and Technological Development, Autonomous Province of Vojvodina, Republic of Serbia.

\section{REFERENCES}

1. AACC (2017). AACC Approved Methods of Analysis, $11^{\text {th }}$ Ed., AACC International, St. Paul, MN, USA, Method 80-68.01 Determination of Reducing Sugars-Schoorl; Retrieved July 2, 2018 from https://aaccipublications.aaccnet.org.

2. Aiking, H. (2011). Future protein supply. Trends in Food Science and Technology, 22 (2-3), 112120.

3. Annor, G.A., Tyl, C., Marcone, M., Ragaee, S., Marti, A. (2017). Why do millets have slower starch and protein digestibility than other cereals? Trends in Food Science and Technology, 66, 73-83.

4. AOAC (2000). Official Methods of Analysis, $17^{\text {th }}$ Ed. The Association of Official Analytical Chemists, Gaithersburg, MD, USA, Methods 925.10, 950.36, 935.38

5. Callejo, M.J. (2011). Present situation on the descriptive sensory analysis of bread. Journal of Sensory Studies, 26 (4), 255-268.

6. Demirkesen, I., Mert, B., Sumnu, G., Sahin, S. (2010). Rheological properties of gluten-free bread formulations. Journal of Food Engineering, 96 (2), 295-303.

7. Duodu, K.G., Nunes, A., Delgadillo, I., Parker, M.L., Mills, E.N.C., Belton, P.S., Taylor, J.R.N. (2002). Effect of grain structure and cooking on sorghum and maize in vitro protein digestibility. Journal of Cereal Science, 35 (2), 161-174.

8. Fruhwirth, G.O., Hermetter, A. (2007). Seeds and oil of the Styrian oil pumpkin: Components and biological activities. European Journal of Lipid Science and Technology, 109 (11), 11281140.

9. Gallagher, E., Gormley, T.R., Arendt, E.K. (2003). Crust and crumb characteristics of gluten free breads. Journal of Food Engineering, 56 (2-3), 153-161.

10. Gallagher, E., Gormley, T.R., Arendt, E.K. (2004). Recent advances in the formulation of gluten-free cereal-based products. Trends in Food Science and Technology, 15 (3-4), 143152.

11. Giuberti, G., Rocchetti, G., Sigolo, S., Fortunati, P., Lucini, L., Gallo, A. (2018). Exploitation of alfalfa seed (Medicago sativa L.) flour into gluten-free rice cookies: Nutritional, antioxidant and quality characteristics. Food chemistry, 239, 679-687.

12. ISO (1994). Sensory analysis - Identification and selection of descriptors for establishing a sensory profile by a multidimensional approach. ISO 11035, International Organization for Standardization, Geneva, Switzerland.

13. ISO (1997). Determination of starch content, ISO 10520 International Organization for Standardization, Geneva, Switzerland, Ewers polarimetric method.

14. ISO (2003). Sensory analysis - Guidelines for the use of quantitative response scales. ISO 4121, International Organization for Standardization, Geneva, Switzerland.

15. ISO (2015). Sensory analysis - General guidance for the design of test rooms. ISO 8589 (Amendment 1:2014), International Organization for Standardization, Geneva, Switzerland.

16. Marco, C., Rosell, C.M. (2008). Breadmaking performance of protein enriched, gluten-free breads. European Food Research and Technology, 227 (4), 1205-1213.

17. Mir, S.A., Shah, M.A., Naik, H.R., Zargar, I.A. (2016). Influence of hydrocolloids on dough handling and technological properties of glutenfree breads. Trends in Food Science and Technology, 51, 49-57.

18. Mirabella, N., Castellani, V., Sala, S. (2014). Current options for the valorization of food manufacturing waste: a review. Journal of Cleaner Production, 65, 28-41.

19. Ogunronbi, O., Jooste, P.J., Abu, J.O., Van der Merwe, B. (2011). Chemical composition, storage stability and effect of cold-pressed flaxseed oil cake inclusion on bread quality. Journal of Food Processing and Preservation, 35 (1), 64-79.

20. Pojić, M., Dapčević Hadnađev, T., Hadnađev, M., Rakita, S., Brlek, T. (2015). Bread supplementation with hemp seed cake: A by-product of hemp oil processing. Journal of Food Quality, 38 (6), 431-440.

21. Popović, L.M., Peričin, D.M., Vaštag, Ž.G., Popović, S.Z. (2013). Optimization of transglutaminase cross-linking of pumpkin oil cake globulin; improvement of the solubility and gelation properties. Food and Bioprocess Technology, 6 (4), 1105-1111. 
22. Popović, S., Peričin, D., Vaštag, Ž., Popović, L., Lazić, V. (2011). Evaluation of edible film-forming ability of pumpkin oil cake; effect of $\mathrm{pH}$ and temperature. Food Hydrocolloids, 25 (3), 470-476.

23. Rodrigues, I.M., Coelho, J.F., Carvalho, M.G. V. (2012). Isolation and valorisation of vegetable proteins from oilseed plants: Methods, limitations and potential. Journal of Food Engineering, 109 (3), 337-346.

24. Ronda, F., Villanueva, M., Collar, C. (2014). Influence of acidification on dough viscoelasticity of gluten-free rice starch-based dough matrices enriched with exogenous protein. LWT-Food Science and Technology, 59 (1), 12-20.

25. Shewry, P.R., Halford, N.G. (2002). Cereal seed storage proteins: structures, properties and role in grain utilization. Journal of Experimental Botany, 53 (370), 947-958.

26. Tarek-Tilistyák, J., Agócs, J., Lukács, M., Do-
bró-Tóth, M., Juhász-Román, M., Dinya, Z., Jekő, J. Máthé, E. (2014). Novel breads fortified through oilseed and nut cakes. Acta Alimentaria, 43 (3), 444-451.

27. Vaštag, Ž., Popović, L., Popović, S., Krimer, V., Peričin, D. (2011). Production of enzymatic hydrolysates with antioxidant and angiotensin-I converting enzyme inhibitory activity from pumpkin oil cake protein isolate. Food Chemistry, 124 (4), 1316-1321.

28. Witczak, T., Juszczak, L., Ziobro, R., Korus, J. (2017). Rheology of gluten-free dough and physical characteristics of bread with potato protein. Journal of Food Process Engineering, 40 (3), e12491.

29. Ziobro, R., Witczak, T., Juszczak, L., Korus, J. (2013). Supplementation of gluten-free bread with non-gluten proteins. Effect on dough rheological properties and bread characteristic. Food Hydrocolloids, 32 (2), 213-220.

\title{
ПОТЕНЦИЈАЛ ИЗОЛАТА ПРОТЕИНА УЉАНЕ ПОГАЧЕ БУНДЕВЕ У КРЕИРАҢУ ХЛЕБА ОД ПРОСА
}

Јелена М. Томић${ }^{*}$, Александра М. Торбица ${ }^{1}$, Миона М. Беловић ${ }^{1}$, љиљана М. Поповић ${ }^{2}$, Јелена Ц. Чакаревић ${ }^{2}$, Даница М. Савановић ${ }^{3}$, Александра Р. Новаковић ${ }^{1}$, Каролина А. Моцко Блажек $^{1}$

\author{
${ }^{1}$ Универзитет у Новом Саду, Научни институт за прехрамбене технологије у Новом Саду, 21000 \\ Нови Сад, Булевар цара Лазара бр. 1, Србија \\ ${ }^{2}$ Универзитет у Новом Саду, Технолошки факултет у Новом Саду, 21000 Нови Сад, Булевар \\ цара Лазара бр. 1, Србија \\ ${ }^{3}$ Универзитет у Бања Луци, Технолошки факултет, 78000 Бања Лука, Булевар војводе Степе \\ Степановића 73, Босна и Херцеговина
}

Сажетак: Циљ ове студије био је да се процени потенцијал изолата протеина уљане погаче бундеве у производњи хлеба од проса. Хлебови су креирани заменом просеног брашна протеинима у нивоима од 5, 10 и 15\%. Одређена су реолошка својства теста, фризичка и сензорска својства добијеног хлеба. Применом реолошких мерења утврђено је да је повећање концентрације протеина уљане погаче бундеве (ПУПБ) утицало на повећање вискозитета теста. То је додатно потврђено нижом еластичношћу обогаћених хлебова у односу на контролни, што је одређено анализом текстуре и сензорском оценом. Замена просеног брашна са ПУПБ у свим нивоима не показује никакав утицај на специфичну запремину хлеба. Међутим, $24 \mathrm{~h}$ након печења, хлебови обогаћени већим концентрацијама ПУПБ су показали мање изражено повећање тврдоће средине, указујући да ови протеини могу да одложе ретроградацију скроба. Обогаћивање просеног брашна са ПУПБ имало је неколико повољних утицаја на сензорски квалитет хлеба, односно смањило је горак укус и накнадни укус хлеба пореклом од просеног брашна. Додатно, зрнавост хлеба се смањила, а брзина растварања хлеба у устима се повећала при повећању концентрације ПУПБ.

Кључне речи: изолат протеина уљане погаче бундеве, хлеб од проса, реолошка својства теста, сензорски квалитет

Received: 28 September 2018

Received in revised form: 29 November 2018

Accepted: 7 December 2018 